\title{
Whose Bible, mine or yours? \\ Contested ownership and Bible translation in Southern Africa ${ }^{1}$
}

\author{
Jeremy Punt \\ Department of Old and New Testament \\ University of Stellenbosch
}

\begin{abstract}
An important but often neglected aspect of the use of the Bible in Africa is its ownership and issues related thereto. Ownership of the Bible obviously concerns its personal possession and all that that entails, but goes beyond the commodification of the Bible in modern consumerist culture to refer, ultimately, to the control of the biblical texts. The limited attention to the ownership of the Bible is mostly restricted to hermeneutics, often identified as a site of struggle in Africa. However, claims to ownership are becoming increasingly visible and up-front in the area of vernacular translations, where such claims and other conditions imposed on Bible translations illustrate the affinity people have with the Book, how their sense of identity and worldviews are moulded by it and how a Bible translation acts as an important player in issues of power at various levels.
\end{abstract}

\section{INTRODUCTION: BIBLE TRANSLATIONS IN AFRICA}

The Bible has been read in translated format, since its earliest years and even when it was still in fragmented form. For many centuries the translation language of choice would be the Latin of the Vulgate ${ }^{2}$ but since the sixteenth century vernacular translations became increasingly common, and on the African continent even more so with the impact of eighteen-century missionary activity. It is often argued that biblical interpretation, in the broad hermeneutical sense of the word, is a site of struggle in Africa, leading to discontent and

\footnotetext{
${ }^{1}$ Paper read at the Bible Translation session of the 2002 SBL Annual Meeting, 23-26 November 2002 in Toronto, Ontario Canada.

2 Jerome's Latin translation of the Bible was completed early in the fifth century, and became the Bible of the (Western) church for the next millennium. He was, however, accused amongst other things of judaising the Bible because of his preference for the Masoretic text above the LXX (Van der Merwe 1999:294; cf Trebolle Barrera 1998:353-7).
} 
conflict among Bible-readers on the continent. My claim is that the issue is not primarily about tension between different hermeneutical models, between trained or ordinary readers, or between Afrocentric or Eurocentric interpretive models, but that it is the contested ownership of the Bible which gives rise to many problems regarding the appropriation of the Bible in Africa, and that Bible translation plays a vital role in the issue of ownership. ${ }^{3}$

Bible translation has a long history on the African continent, with one of the earliest and certainly one of the most influential translated texts, the Septuagint ( $L X X)$, raising issues not unfamiliar today. The Hebrew Bible translated into Greek came into existence on African soil in Alexandria ostensibly during the latter half of the third century (c 280-260) BCE, commissioned by Ptolemy II Philadelphus. Today it is commonly accepted that the Septuagint had a longer and more complex history of development than what was often assumed or claimed in the past. And whereas at a later stage its position in the Christian church and in Protestantism in particular was determined by theological considerations, this translation seems to have led to some uneasiness and reservations. The anxiety was not so much caused by issues regarding the translatability of Holy Scripture or speculation on the inspirational nature of the translation, but was due rather to the inability to render a translated text identical to the original, indicated for example by comments to that effect in the prologue to the translation of Sirach (Müller 1996:41-45; 66-67).

However, the Septuagint as the Bible of the Gentile Christian Church was abandoned in the West, mainly for theological reasons, but also because of the growing influence of Latin-speaking Christianity. In fact, Christianity's retreat from Roman North Africa some centuries later was, at least in part, ${ }^{4}$ due to the dominance of Latin as official language of the church (Schaaf 1994:14$17)$, and "[t]he failure to produce a Punic version of the Bible was an ill omen for the church in North Africa" (Sanneh 1989:69). Inversely, the prominence of Christianity in the East was related to its embrace of local languages such as Syrian, Coptic, Ethiopian, Armenian and Greek (Gibellini 1994:2). The translation of the Bible into contemporary African languages, although a

\footnotetext{
${ }^{3}$ My perspective is deliberately broad, as is typical of the use of translated Bibles, and includes references to trained, theological as well as ordinary, devotional and spiritual use of the Bible.

${ }^{4}$ Other factors for Christianity's disappearance from Northern Africa was the doctrinal (e g Donatist, Monatist, and Arian) controversies which divided and weakened it, and the prevailing perception that Christianity was an elitist religion, e g through the exclusion of the Berber peoples during Christianity's early years (Obeng 1997:24 n23; cf also Schaaf 1994:1617).
} 
relatively recent phenomenon, ${ }^{5}$ going back to the Christian missions of roughly the last two centuries, has put the focus on the role of vernacular translations in Africa.

Translating the Bible in Southern Africa today is subjected to two oppositional drives, one towards maintaining boundaries and perimeters to secure control, and another of challenging both the boundaries and their accompanying controls. Van Toorn's claim regarding the use of the Bible in Australia (Tasmania) holds true for Southern Africa as well. "The more widely the Bible was disseminated across cultural borders, the greater was the dialogizing pressure toward semantic fragmentation through translation and cultural recontextualization, and the stronger in many cases was the reactionary monologizing impulse to hold that fragmentation in check" (Van Toorn 2001:42-42). All texts, and especially those disseminated and used widely such as the Bible in Southern Africa, encounter two powerful forces which have been described by Bakhtin and others as centripetal and centrifugal, or monologising and dialogising. Centripetal or monologising forces are powerful efforts to "centralise hermeneutic authority, suppress ambiguity and ambivalence, and curtail the practice of reading differently". In contrast, centrifugal or dialogising forces entail practices which allow and stimulate ambivalence and diverging interpretations. Both centripetal and centrifugal forces are important elements to account for in the proper use of the biblical texts, since the Bible can easily degenerate into dogma unless it is consistently re-interpreted or re-incarnated (Ong), as much as it can fragment semantically under extreme dialogisation, becoming nothing less than cacophony or dissonance.

It is within the tension field between these two ranges of powerful forces where Bible translation in Southern Africa finds itself today, and where the issue of ownership of the Bible emerges forcefully. ${ }^{6}$ Perhaps more than elsewhere, the social identities and self-perception of many people in predominantly Christian southern Africa are still refracted through the prism of religious and a biblically-infused identity. Being more than just a religious text in Africa, the Bible also assumes a social role where issues of proprietorship,

\footnotetext{
${ }^{5}$ Excluding the Old Latin version from Carthage in the third century, or the Sahidic (Upper Egypt Coptic) Bible from the end of that century, or soon thereafter the Bohairic and Bashmuric Bibles. The Ethiopian Bible, in Ge'ez, might be dated as early as the fourth century (Schaaf 1994:12,14,21). For a taxonomy of Bible translations in African languages by 1885, cf Schaaf (1994:91-3); for a more recent picture, cf Schaaf (1994:132-44).

${ }^{6}$ As will be explained below, ownership concerns more and extends beyond the scholarlytheological versus ecclesial-devotional claims made on the Bible, the tension that was recently if one-sidedly addressed by Davies (1995).
} 
alongside translation and hermeneutical concerns, are brought to the fore. To this, we will first turn our attention.

\section{SOCIAL ROLE OF THE BIBLE IN AFRICA: AN INCENTIVE FOR OWNERSHIP}

In Africa the translated Bible is the book with the widest circulation figures, read, studied and used by an astonishing variety of people for religious and related purposes. "There is no doubt that the Bible is the most influential, most widely translated and the most widely read set of documents in contemporary Africa" (Mugambi 1997:78). But translation has been and always will be contested, at least when it is accepted that translation and interpretation are inseparable, and that no single translation can do equal justice to both original and receptor languages, more especially given the vastly different sociohistorical contexts along various chronological lines. If it is true as Manus (2001) claims, that the - most often, translated - Bible is the main source of theology in Africa, ${ }^{7}$ it is not surprising that many a claim is made concerning its proper translation and reading in Africa. And if the Bible in Africa is indeed about more than matters religious, spiritual and devotional, and include sociocultural matters as well, ${ }^{8}$ the significance of translated Bibles is maybe even greater.

\subsection{Interconnected religious/theological and social roles of the Bible in Africa}

The importance of the Bible in Africa is underscored by challenges to its translation and reception, and the variegated, disputed and unstable profile of biblical hermeneutics on the continent. The importance of translation in and for African Christianity is noticeable in the broader discussion, which involves more than mechanical and technical issues. Christianity is a "translation phenomenon" because since its earliest years "Christianity formed and spread through the continual effort of creating and translating new terms and concepts" (Trebolle Barrera 1998:125). Translation becomes a metaphor for the

\footnotetext{
${ }^{7}$ The claim that the Bible is considered by African theologians as the primary "source and norm of all Christian knowledge and the evidence of the divine will toward all humanity", as the "diving board" (Martey 1993:71-2), or "jumping pad" (Wambudta 1980:33) from which African theologians initiate their efforts, is often heard but also contested.

8 "Translating the Bible into these African languages has meant, among other things, putting it right into the heart of African cultures" (Mbiti 1994:27). "Even to those with little religious inclinations, the Bible has proved to be important in its existential reflection on life and the human condition" (Nthamburi and Waruta 1997:49).
} 
inculturation of the Gospel, ${ }^{9}$ characterised by the incarnational quality of Christianity exemplified in Jesus Christ (Sanneh 1989:3; also Schaaf 1994:207). The vernacular Bible became the primary vehicle of local Christianity, since "the process of translating the Bible submitted the Christian faith to the terms of the local culture" (Nthamburi and Waruta 1997:42). Such influence of translated Bibles is noticed in their contribution to the formation of local or indigenous churches, ${ }^{10}$ theologies as well as to social and cultural development in Africa. ${ }^{11}$ Bible translation activities regularly initiated the first detailed inventory of local language and culture ${ }^{12}$ (cf Mbiti 1986:24), leading to far reaching consequences and - in subversive contradiction to the often dominant Western paradigm of the missionary translators - often provided the impetus for nationalism ${ }^{13}$ (Sanneh 1992:16-17). Against the background where vernacular Bibles became the backbone of African Christianity, but also informed the socio-cultural fibre of African communities as from around the middle of the nineteenth century, translated Bibles were soon however

${ }^{9}$ On inculturation, cf e g Bevans (1992: esp 30-46) and Schreiter (1985: esp 6-9); in Africa, also Bediako (1994:246-7). Maluleke criticises Sanneh and Bediako for their insistence on the "translatability" of Christianity and, respectively, for the attempt to disconnect African Christianity from Western colonialism and imperialism, and for the reaction to the African intellectual critique on Christianity (1996: esp 3-8).

${ }^{10}$ Surveys show that the incidence of founding new, independent churches was higher amongst communities in possession of vernacular Bibles (cf Bediako 1994:246; Combrink 1996b:282; cf Schaaf 1994:208), where local communities could engage the texts and their meaning on the communities' own terms. The vernacular Bible was taken as "proof" of a link between the local divinities and the God of the Bible, and that "they embody God's revelation and truth" through the translation (Nthamburi and Waruta 1997:43; cf Mbiti 1986:29-31). In one example, the translation of the Christian Testament into Gikuyu in 1926 coincided with the conflict between Christian missionaries and Gikuyu Christians about traditions and customs, e g polygamy, dance and female circumcision, and resulted in the founding of the Akurinu church in 1927 (Ndungu 1997:60).

${ }^{11}$ Although not an uncontested notion, vernacular Scripture is believed to have contributed to the development of people of the Two Thirds World, through strengthening their self-respect and dignity, expanding their life-worlds, contributing to literacy and promoting a new sense of identity (Whiteman 1992:134-6; cf Mbiti 1986:26-7). Cf also the interesting comments by Walls on how the Septuagint translation contributed to the Platonic and Stoic debates on the nature of law, reality and the Greek logos-idea (1992:29).

${ }^{12}$ Cf Dahunsi (1972:117-120). This is, however, not unlike the early years of Christianity, where translated Bibles would present those on the frontier zones of the Roman Empire with the first literary corpus of their future reservoir of national literature; examples include the Armenian, Ethiopic and Old Slavonic translations (Trebolle Barrera 1998:125). ConstantineCyril's translation of the Roman Mass into Slavonic in the 9th century led to the creation of the Cyrillic alphabet (Sanneh 1989:73). For an optimistic view of Christianity's contribution in general to the development of the vernacular, cf Sanneh (1989:51-3).

13 "An important difference, however, is that mission furnished nationalism with the resources necessary to its rise and success, whereas colonialism came upon it as a conspiracy" (Sanneh 1989:106). Sanneh is at times more reluctant to separate mission and colonialism, reminding his readers that the growth of new Christian churches after the twentieth-century independence of African states indicates how colonialism inhibited the spread of the gospel (1989:112). 
trapped in the question of their proprietorship, alongside the control of their meaning.

The Bible is in the Southern Africa of today widely perceived as a significant and meaningful text, a foundational document (Scroggs 1995) with a life-giving quality (Camp 1993:161-163), and it is irresponsible to ignore its involvement in matters related to religious and social identity (cf Schaaf 1994:202-203 for Southern Africa). The relationship between identity formation, maintenance and transformation, and the Bible cannot be ignored. The formative and sustaining role of the Bible in fostering a sense of identity among believers and in communities can be described as enscripturalised identity. ${ }^{14}$ "Christian communities are constituted and reconstituted politically by Scripture, because Scripture provides the primary context for understanding what it means to live faithfully before God" (Fowl and Jones 1991:36). In Christian, and Protestant communities in particular the Bible often becomes a mode of identity, as these documents contribute in different ways to open up other worldviews, to create different realities. As Scripture, the Bible is a document which enables and helps us "to understand ourselves and our fellows as human beings" and "to understand the world - the cosmos - in which we live" (Smith 1993:238; cf Schüssler Fiorenza 1993:9-11). Enscripturalised identity entails not only self-definition in communal and individual sense, but also the identification of difference, of the Other, through the interpretation and appropriation of the biblical texts. The Other is also scripturally - and often, textually - inscribed. The relationship between hermeneutical processes of identity and othering, and social identity and othering is worth noting, especially against the background of a pragmatist or interpersonal reading perspective: Hermeneutical and social otherness is interrelated.

If the circular movement of interpretation is accepted, namely that while hermeneutical considerations are interrelated to and at times dependent upon worldviews, those very worldviews are the result of and prescribed by hermeneutics (Westphal 1997:65), our interpretations of the Bible cannot stand aloof from the configuration of our lives. Enscripturalised identity entails more than using the Bible, especially when perceived in an atemporal, asocial and ahistorical sense, as legitimating agent for an assumed and historically developed identity, and for justifying the identification and vilification of the

\footnotetext{
14 "Enscripturalised identity" is not offered as the full extent of (determining) Christian consciousness and character: many other elements are involved in the formation of Christian identity (cf e g Fowl and Jones 1991:44-49, on the importance of "readings of the world"). Enscripturalised identity, however, is arguably one of the most important constituent elements of Christian identity as much as it does not require or imply a "totalising discourse" (Foucault). "Enscripturalising" may be an even better, if more clumsy, word to underline the dynamic and active nature of what transpires between community and Scripture.
} 
Other as defined in terms of ourselves. ${ }^{15}$ Enscripturalised identity rather requires one to comprehend Others on their own terms, to interact both with Others, and their interpretation of the same or other texts. ${ }^{16}$

Processes of othering emerge in Bible translations' less benevolent achievements. While the contribution of translated Bibles to indigenous languages provided utilitarian tangibles in the form of grammars, dictionaries and lexicons, they assisted colonising agents to acquire a working knowledge of the languages in order to exert even more effective rule, administer justice and collect revenues. The translated Bibles, moreover, proved valuable in the education of indigenous people and contributed to their embracing of consumer class values. They became the servants of the colonial endeavour by reinforcing stereotypical images of the Other. Racial superiority supported by the Western, progressive notion of history was achieved through demonising the Other and by emphasising racial, gender and class differences. So Robert Moffat could assert about the people of Botswana, "[T]hus by the slow but certain progress of Gospel principles, whole families became clothed and in their right mind" (Sugirtharajah 1998:88-89).

\subsection{Ownership of the Bible in Africa}

"The battle over the Bible in South Africa ... is a contest of conflicting claims over legitimate ownership of that constellation of sacred symbols" (Chidester 1991:22).

Historically, ownership of the Bible relates to claims in this regard on behalf of Judaism, Christianity and Western or world literature, in particular concerning the ability to authorise or sanction the list of texts deemed to properly belong to the biblical corpus. Beyond the power to include or exclude texts, ownership also lies at the heart of claims about the canons of the Old Testament, the Septuagint, Judaism, the early Christian church, Greek and Eastern orthodoxies, Roman Catholicism and the variety of Protestant groups and churches. Such canons are of course not constructed for their own sakes, but are seen as the source of theologies and doctrines or at least the inspiration for such constructions, at times acknowledged and approved by religious

\footnotetext{
${ }^{15}$ Indeed, one also seriously has to consider, apart from the question of whether or not the Bible is demonstrably linked to the construction of identity, whether all those implicated would necessarily countenance such a link. Cf e g Banana (1993:17-32); Camp (1993:154-171; esp:160): Indeed, a relationship to the text to the extent that it is personified in the life of the individual or community, is decried by some feminist scholars.

${ }^{16}$ Identity in religionism ("a form of religion in which the individual and collective identity of one religious group is maintained by asserting negative aspects of the other") is dependent upon sentiments and mechanisms of rejection and exclusion (Sugirtharajah 1998:93). Apart from reckoning with the otherness of the biblical texts on historical and literary levels, it has to be kept in mind that the Bible itself can become an outsider to Christian communities and individuals, when it is read over against them (Segovia 1995:298; cf McDonald 1993:200ff).
} 
organisations, and crafted most often in relation to religious communities (cf Betz 2000:5-6).

In Southern Africa, however, ownership of the Bible is disputed within a predominantly Christian religious setting. Ownership most obviously relates to the simple fact that many people and Christian communities in particular aspire to possess a Bible of their own, regardless of the ability or propensity to read it, but the notion of Bible ownership extends beyond the commodification of the Bible in modern consumerist culture, its buying-and-selling power. It concerns claims to the biblical texts, the right to interpret their meaning, to prescribe and proscribe their contemporary use,$^{17}$ the nature of the relationship between the Bible and one or more communities, the privilege of claiming a specific identity natured and fostered by the Bible - claims some of which are made in a totalitarian and exclusionist way. In short, ownership is about claims regarding the control of the biblical texts.

Ownership can be constituted in a variety of different ways, ranging from claims to the Bible as the unique or exclusive property of one group, to proprietorship through activity, namely when the production, distribution and systematic reflection on the Bible reflect high levels of energy and activity invested by interested communities. Ownership of the Bible, therefore, need not necessarily be accompanied by explicit claims to these texts for the benefit of the community, since the notion of ownership is already perceived in the attachment to the texts portrayed in attitudes and activities linked to the production and dissemination of the texts and their readings. In Southern Africa, ownership claims regarding the Bible relate to either a religio-theological or a cultural-political context, or both, especially since on the African continent such distinctions are often arbitrary. Religio-theological concerns relate to churches and their structures, and the notion of negotiating divine power. Cultural-political matters are concerned with issues of identity and nationalism, using the "master's tools" and negotiating power in a more general sense, and the notion of the Bible as the text of the oppressor as opposed to the Bible as a liberating, empowering text. It is not wise, therefore, to distinguish too sharply between religious and cultural ownership on the African continent. ${ }^{18}$

The issue of control of or power over the use of the Bible should not be seen as a predilection of opportunist or imperialist cultures, communities or individuals: every community claiming allegiance to it in effect asserts its

\footnotetext{
${ }^{17}$ This includes the widespread "magical" use of the Bible, in healing practices (Ndungu 1997:62-63) or where the possession or touching of the Book is considered beneficial (Waliggo 1997:179). Recently, West (2002:23-37) has proposed the notion of the Bible as bola (prognosticating dice) as a metaphor for understanding the Bible in Africa.

${ }^{18}$ The importance of vernacular translations of the Bible in Europe during the period of the Protestant Reformation can probably also not be explained with an exclusive reference to either religious or political concerns.
} 
particular authority on the Bible's use. ${ }^{19}$ The Bible's formative influence depends on whether there are "powerful enough communities, institutions, establishments" ${ }^{20}$ whose reading and constructing of the Bible impacts on the South African society. The increasing realisation that the ownership of the Bible relates not only, and not even primarily, to the context of its production but rather to the context of the reader, is a corollary of the acknowledgement of the reader's active or formative role in the process of biblical interpretation (cf Combrink 1996a:299). Communities assert authority over the particular way and manner of biblical appropriation in their claims for possession of the Bible: "communities and traditions of interpretation construe unity within the diversity of the Bible and call their construct 'the Bible"' (Smit 1991:61-63). ${ }^{21}$ In South Africa the Bible has become a "site of struggle" (West 1994:273-289) between various communities, and "the struggle is fought over the power, the authority, to be able to determine the contents and the message of 'the Bible'" (De Villiers 1993:13-16). ${ }^{22}$

\section{THE BIBLE AS COMMON PROPERTY? THE ROLE OF TRANSLATED BIBLES}

"Who owns the Bible? The fact is that nobody "owns" the Bible ... none of the Christian churches own or are in control of the Christian Bible" (Betz 2000:10)

A perception perhaps more common to the Western world in general than Southern Africa, is that the Bible is common property, belonging to all, and therefore, is not the property of anyone in particular, as Betz contends. Indeed, "the Bible belongs to Africa as well as the Western world" (West 1999:45). As the public, cultural property of those who read it and wish it to be theirs, it belongs to everyone or every community who claim it for themselves in

\footnotetext{
19 "All acts of communication, also in the Bible, reveal a struggle for power" and "the Bible we so often hold in a grasp of power, is often nothing but our own ideologies and idolatries" (De Villiers 1993:20). "Of course we must recognize that revolutionary interpretations of Scripture can be [sic] as ideological as interpretations by those in power, just as feminist interpretations can be [sic] as ideological as patriarchal interpretations" (Bauckham 1989:18).

${ }^{20}$ Amidst an accompanying ambiguity: In SA, biblical scholarship with its "scientific ethos of detached enquiry" has had a negative role regarding the public ethos: "it has stayed clear from the corridors of power in both church and society" (Smit 1991:61-63). On the other hand, scholars are found to use the Bible "to entrench the norms and values of the upper classes thereby creating their exclusive ideological institutions like journals, manners, and morals" (Mazamisa 1995:12). Cf Brenner (2000:11): "Although the Bible's democratization was greatly enhanced by translations into vernaculars, it remained confined in elite secrecy", and biblical scholars have a vested interest in this, "hoping to perpetuate our own influence in the texture of our culture". Translators and translation work face similar ambiguities.

${ }^{21}$ While Smit asks questions about the nature of the Bible, he in fact also answers some questions pertaining to the ownership of the Bible: communities construct their own Bibles for their own particular purposes.

${ }^{22}$ In SA public, and especially political life, the Bible is often used in a sanctioning role: "appeals to the Bible ... significantly contributes to the effectiveness of an argument" (Botha 1996:335).
} 
religious, spiritual, cultural or other senses. Printed and more recently, electronic, copies of the Bible abound, while bookstores and libraries stock various translations and versions of the Bible, and although this is not in particular good reason for doing so (Betz 2000:10), communities, institutions and people do not refrain from claiming to be the owners of the documents, whether in the original or processed format.

In the end, the impossibility of owning the Bible probably dispels the claims to ownership of its interpretation and meaning in equal measure to making it more prone to such claims. Unlike the ancient Hebrew and Greek versions, or Bibles in the languages of the colonisers, translated Bibles relativise all claims to the ownership of the Bible as much as it offered (and still does!) the opportunity to various peoples to lay claim to the Bible.

\subsection{Linking translation and ownership}

"The unquenchable desire of Americans for the possession of the Bible and a willingness to accept a translated Bible combine to proliferate translations" (Frerichs 1988:2)

At times the notion of the Bible as belonging people to all people, is supplemented by a claim that it shows a predilection for a certain context, or group of people. Some instances in this regard are the debate about the greater receptibility of the Hebrew Bible in Africa, and the consideration of the "Africanness" of the Bible. Claiming ownership of the Bible in African Christianity today assumes many forms, ranging from the insistence that the conceptual framework of Hebrew is closely aligned with those of African languages in general (e g Rabin 1972:115; Turkson 1994:74-80) to the more widespread demand that the African cultural context should be acknowledged as analogous to the setting portrayed in the Bible, in particular that of the Hebrew Bible (Schaaf 1994:197-198). The oral context of the first century is evoked with the claim that "on the African scene the Bible relives a large part of its original setting with regard to the channels of communication and uses of language" (Mbiti 1994:30).

The desire of Christian communities and individuals to own their own, readily understandable Bible has stimulated translating activities over many years, in America as Frerichs points out, but also in Africa where the largest variety of languages is found. And, conversely, translated Bibles were the direct stimulus towards the ownership of the Bible, which, once translated, is no longer seen as an outlandish and foreign book since it can then be read widely, in the vernacular and generally in accordance with the worldview of its readers. As expressed so often, people in Africa now find God addressing them in their 
own language and not that of the coloniser or invader ${ }^{23}$ In ceasing to be a European book - the white man's book - the Bible now became the people's book, and therefore on the African continent, it has also become an African book (Schaaf 1994:204-210). Where biblical translation work in Africa took the indigenous particularity serious translated Bibles contributed to the fostering of cultural pluralism within Christianity on unprecedented scale (Gallagher 1996:238-239). And translated Bibles inevitably impinged not only on a monolithic approach to interpretation, a missionary reading as it were, but necessarily challenged the control of these texts.

Vernacular translations meant that the control and ownership of the Bible were wrestled away from missionaries in the nineteenth century Africa (cf West 2001:212). From the perspective of India, Niranjana (in Johnston 2001:28) claims that "missionaries, anthropologists, and colonial administrators systematically collaborated in the consolidation of colonial domination, through their involvement in translation of both Indian and Christian texts". Colonialism as an ideology, and a hegemonic culture, was bound up in missionary translations. It was, ironically though, also the translation of the Bible into other, vernacular languages which "opened up a space for colonial difference to emerge" (Johnston 2001:27). Translations in colonial contexts permitted and even stimulated the possibility of a wide-ranging field of interpretations, and so dislodged the powerful position of the European missionary as the only interpretive authority. "The key issue here, though, is one of authority to interpret the words of God. Translation opens up the potential for destabilising European authority; the response to such destabilisation is to reinforce dominant modes of interpretation or definition" (Johnston 2001:29).

As is illustrated in an anecdote recounted by Sugirtharajah (1998:123), a translated Bible claimed as the benevolent gift from the West to indigenous peoples whether in India or elsewhere, generally ensured that it remained under European control and maintained its Western character. But when indigenous people claim the translated Bible as originating among themselves, they not only register a claim for a different biblical genealogy in their identification with the Bible and its content, but they simultaneously deny Western control and assert their own ownership of the Bible. ${ }^{24}$

\footnotetext{
${ }^{23}$ The African context is different from the Asian which Sugirtharajah (1998:123-141) describes, in one aspect in particular, namely the existence of other Scriptures. In Southern Africa, at least, the introduction of the Bible was not so much accompanied by competing scriptural claims as by questions regarding the relationship of the Bible vis-à-vis traditional African religions, beliefs and practices.

${ }^{24} \mathrm{Not}$ forgetting that a translated Bible can also become a pivotal element in forms of postcolonial nationalism, mimicking the ideological power of the colonisers, and their mechanisms of exclusion.
} 


\section{TRANSLATING AND OWNING A "REWRITTEN" BIBLE: CONTROLLING THE TEXT}

For many in Africa the governing image of the Bible is related to the adage that the missionaries traded the Bible for the land of the Africans. Whether the indigenous people of Africa got the better deal (Tutu) or not, ${ }^{25}$ the Bible was indeed the "time-bomb" which would eventually help to blow colonialism apart (Schaaf 1994:166), not only, but also, by providing subversive texts and readings. One should be careful with the anecdote, since in its metaphorical way, it hides as much as it exposes and to take it too literally or to focus on a single aspect of the whole, would certainly distort its meaning and render Tutu's retort incomprehensible. It can help to recognise how the availability of vernacular Bibles enabled a powerful backlash against colonialism's particular effectiveness in intellectual and cultural control (discursive colonialism), especially since it surpassed its territorial and political domination.

\subsection{Rewriting: The ultimate translation}

Vernacular Bibles which were the tools of the trade in indigenous reactions and responses to colonialism, as well as in fostering a new identity and selfawareness in its aftermath, could not escape accusations of imperialist complicity when the anti-colonialist argument turned full-circle. Not surprisingly then, critical voices both from within and outside the Christian tradition were raised against translated Bibles and their influence on indigenous and traditional beliefs and practices in Africa. Some of the strongest claims regarding biblical ownership have been made in the rereading or rewriting of the Bible-debate, a debate closely linked with translation. Certain African theologians have been making very strong claims for the revising of the biblical canon and texts to more adequately reflect African sensitivities, to disclaim texts deemed oppressive to the African mind, and to render a Bible which will be African user-friendly.

In Africa the name of Canaan Banana is often the first to be linked to the call for a rewritten Bible, ${ }^{26}$ promoting "The case for a new Bible" (Banana 1993:17-32). In short, Banana argues in this essay that the Bible has yet to be

\footnotetext{
${ }^{25}$ Cf West's (2002:23-37) recent attempt to understand ownership of the Bible in Africa with reference to this anecdote. Most recently during early March 2002, in the run-up to the presidential elections in Zimbabwe, the Secretary of the (then) ruling ZANU-PF party, Mr Didymus Matase, also recalled the metaphorical trade-off of the Bible for the land of the indigenous people. He added that the people of Zimbabwe now want the land (referring probably to white-owned commercial farms rather than the large tracts of land handed out to the party faithful) back, and that the erstwhile colonial rulers can have the Bible back, should they want it! (As reported on Special Assignment, SABC3 on Tuesday 5 March 2002).

${ }^{26}$ Cf also Mofokeng (1988:40). Parratt (1995:148-153) provides a short biographical sketch and brief introduction to Banana's theological views. Cf the introduction of Mukonyora, Cox and Verstraelen (1993:x-xiii) for a historical account of Banana's call, claiming that it became a "catchword that inflamed an intense controversy".
} 
liberated from its culture-specific views, points to the use of the Bible as oppressive instrument, ${ }^{27}$ and insists on the continuing revelation of God, and that the person of Christ supercedes the Bible. He claims that the purpose of the Bible was to unite Christians against forces that wanted to divide them and that we need to recreate the Bible into such a "unifying element" again. "This [rewriting of the Bible] would include revision and editing to what is already there, but would also involve adding that which is not included" (Banana 1993:30). In short, what amounts to the modification of the existing historical texts is proposed. Although there is much to commend about his concerns with the Bible and its use today, Banana needs to be questioned on his insistence that "re-writing is a necessary component to liberating the Bible" (1993:17).

The rewriting appeals originate in the translation venture no less, go beyond a tailor-made Bible however, and are indicative of the effort to produce a text which would reflect the identity and sentiments of its readers in a particular context. "Translation in a postcolonial context is not merely seeking dynamic equivalence or aiming for linguistic exactness, but desires to rewrite and retranslate the texts, as well as the concepts, against the grain. Rewriting and retranslating are not a simple dependence upon the past, but a radical remolding of the text to meet new situations and demands" (Sugirthrajah 1998:97). But some caution is advised, since as argued above, translated Bibles contributed to and fostered the development of an independent consciousness and nationalism, often assisted in the establishment of a literary language and legacy which in turn contributed to increasing independence from the coloniser's ideology and worldview, as well as imperialistic attitudes and hegemonic practices. ${ }^{28}$

The challenge for all attempts at rewriting the Bible is that once the rewritten text is actually produced, the quest for the next rewriting will begin, guided as it is by historical (temporal and spatial) contingencies and given our fast-changing global village in the information-age. More importantly, this debate is prominently about control and canon, about ideology and power, rather than about a nostalgic notion of (re)discovering Africa in the Bible, or the Bible in Africa. Rewriting is about re-inscribing the Bible, the canon, once again as all-powerful, self-contained repository of truth, and the lingering effects of such perceptions of the Bible might outlast other, more material hegemonies,

\footnotetext{
${ }^{27}$ On the other hand, cf Pollard's (1995:47-50) three reasons for holding on to the Bible in its current form even though it was used in the past as instrument of oppression; also Punt (1998:279-280). In the US context, Cone argued that the notion of the Bible as "Word of God" limited Whites' use of the Bible in the oppression of Blacks (Mosala 1989:15).

${ }^{28}$ Vernacular translations became vehicles of "epistemic transformation", rather than signs of imperialism, since it provided the means for transforming thought and expression (cf Sugirtharajah 1998:129, referring to Spivak).
} 
in the wake of dispossessing the colonising and still imperial West from the control of the (their) Bible.

\subsection{Canon and control}

"As I have become more aware of Christianity's claim to ownership of the biblical texts, I have wanted to dispute that claim, to "steal" away the texts and to allow them to sink or float on their own in the secular cultural currents of our times, just like any noncanonical text does" (Aichele 2001:11-12).

Viewing the biblical canon as a neutrally aligned set of documents, each written in its particular circumstances and eventually gathered in the form available to us today, is no longer - if it ever was - possible (Barr 1990:156; Cormie 1991:185ff; Mosala 1989:9). ${ }^{29}$ However, as much as the naive acceptance of the biblical documents in canonical form as ideologically neutral is frightening, it is alarming that another selective, interest-laden if not exploitative, process of composing a biblical canon might become its substitute. ${ }^{30}$ Such an all-consuming and determining selection of biblical texts may in the end, and notwithstanding whatever good intentions, only succeed in emulating and thus perpetuating the practices which the colonisers and oppressors of Africa were guilty of in this regard.

The question of the canon therefore inevitably arises when thinking about biblical ownership, taking into consideration that the documents of both the Old and the New Testament were in circulation and in use before the Jewish and Christian canons were fixed. It is with the concept of canon that the ownership and translation link is cemented, since "Christianity seeks to possess the biblical contents in the form of ... a 'work' ... a self-identical, ownable thing ... a canon" (Aichele 2001:70). Although the canon makers considered earlier developments towards canon formation, it was second to fifth century theological criteria as well as legal and social concerns of the time that governed the final compilations. With both the Church and Synagogue facing tremendous growth in movements and literatures, writings suitable for liturgical worship, for authoritative proof-texts for decisions and doctrines and for establishing religious-social boundaries between orthodoxy and heresy ruled

\footnotetext{
29 "[T] he canon ... [is] an ideological vehicle for domination and oppression" (Van Aarde 1994:578). It has been pointed out how a "the Bible says-theology" was and is used to justify patriarchy and the oppression of women in African society at large (Oduyoye 1995:173176;189-192; cf Smit 1994:275). To this can be added the justification which is still found in it for racial segregation and supremacist thought, homophobia and various others.

${ }^{30} \mathrm{E}$ g, Banana's (1993:17) proposal includes a Bible which is not culture-specific, imposing the modernist ideology of neutrality on the culture of his choice, as his insistence on having other materials included in the Bible might go beyond their accessibility (Banana 1993:18), to impose a kind of bibliolatry through the Bible of his choice.
} 
the day (Betz 2000:10). In the Christian church, the canon gradually but increasingly became an instrument to control meaning.

The real struggle concerning the Bible in Africa is the struggle for its control, especially in order for "contemporary Blacks to assert their claim on the Bible as a weapon of ideological and spiritual struggle for liberation", and viewing the Bible "[i]n the absence of a better storeroom of ideological and spiritual food ... for an undeterminable period of time to be the haven for the black masses par excellence" (Mofokeng 1988:39). The debate on the form of the biblical canon, on the texts contained therein and especially the interpretation thereof cannot be divorced from power relations as these also emerge in the Afrocentricity and Eurocentricity debate.

Translation leads to either a loss of control or a shift in the control of the texts, since through vernacular translations ecclesial and related institutions, although initially often controlling the translation processes, lose such influence upon completion of the project, and as control of the (translated) Bible shifts to the Bible-using communities.

\section{RECOLONISING TRANSLATIONS: OWNING UP}

Bible translation is important in Africa among the cultural and linguistic variety and richness of the continent, and serves the obvious, if by no means unencumbered, purpose of making the Bible available to an increasing number of its peoples. However, amidst the largely foreign funded Bible translation activities in Africa - a condition which is exacerbated by African governments and organisations who do not seem to see the need for investing in them - "foreignness" in Bible translation seems set to remain an abiding feature of many translations in the foreseeable future (cf Obeng 1997:19-21). In fact, the contribution of translated Bibles in general and certain translations, in particular, to the decolonisation of African society and theology has been challenged, primarily on the grounds that the coloniser's ideology was often maintained in the translated product. ${ }^{31}$ Rather than subverting the oppressive legacy, translated Bibles can re-impose an ideology both foreign to and repressive of African people. Translators as well as the theory and practice of translation are blamed for continuing an imposing and at times imperial legacy exacted primarily by the wide-ranging influence of translated Bibles in Africa.

\footnotetext{
${ }^{31}$ In many parts of Africa, English literature came to replace the Bible, and the evangelical ambitions of Christian missionaries were "to become the most influential medium for the colonial civilizing mission" (Gandhi 1998:144). Cf Sugirtharajah (1998:86-98) for the role of Bible translation in both colonial and postcolonial India.
} 
Postcolonial sensitive translations not only have to consider the original language-receptor language relationship, and debates on translation theories such as whether literal or ideolectic or functional-equivalent translations are more appropriate. Breaking with the notion of the universal validity of AngloAmerican English, even English translations will do well to accommodate vernacular idioms, syntax and poetics, and celebrate the hybridical and multicultural nature of our postcolonial world (Sugirtharajah 1998:94). In Africa where a translated Bible often marked the first excursion of a language into the literary world, a reality is nevertheless interpreted in different ways. It is the translated Bible which becomes the vehicle through which a language is moulded in literary sense, ${ }^{32}$ simultaneously enriching the language through neologisms and new concepts and expressions (Mbiti 1994:28). Such imported terminology often becomes part of the vernacular to such an extent that when newer translations use more contemporary and "politically correct" terminology, they are viewed with suspicion. However, the treasured elements of earlier Bible translations often end up disabling the traditional conceptual framework manifested in that language. ${ }^{33}$

When people claim affinity for a specific translation of the Bible, both in terms of its texts and canonical forms as well as its terms, concepts and language style, it not only has implications for new translations but require negotiation with ownership claims. The use of language to create reality and mould the world necessarily has implications for the use and importance of indigenous concepts. Indigenous categories are important not only for theologising, but even more so for Bible translation. ${ }^{34}$ However, it is a finely-

\footnotetext{
${ }^{32}$ Cf also Ntamburi and Waruta (1997:42-3), who add that literacy itself was encouraged, with the ability to read often being a requirement for baptism.

${ }^{33} \mathrm{Cf}$ also the so-called "union literary language", a syncretistic mix of different dialects (Schaaf 1994:109). A related problem is that biblical terms are often translated with words and concepts, which operate in the context of traditional African religious experience. Employing Geertz's distinction between "experience-near" (emic) and "experience-distant"' (etic) concepts or symbols, Van der Jagt explains how a particular African context (the Turkana of Kenia) highlights the problem of the equivalence of religious terms across cultures and its related difficulty for Bible translations (1990:131-53). The extension of this argument is the propagation of Africa's "primal religions" as prepaeratio Evangelica (Bediako 1994:24751), which ironically and inevitably leaves very little of these religio-cultural frameworks intact. It is not so consoling to argue then that the translatability of Christianity is a counter-measure against cultural idolatry or romanticism (so Sanneh 1989:112), when the boon of Christianity's translatability may also be the bane of an imposing hegemony. Indeed, the pluralism which follows in the wake of translatability ("the source of the success of Christianity across cultures", Sanneh 1989:51) too often fits into the Christian master (imperialist) narrative (cf Aichele 2001:80-83).
}

${ }^{34}$ Cf e g Mugambi (2001:13-17; 22-24). Dube's strong reaction regarding the translation of Badimo in the Setswana Bible is not only about reclaiming ownership of a translated Bible, but attests to how such claims play out in the use of indigenous concepts (Dube 2001:145163). 
poised balance since the danger of ethnocentrism (cf Sze-Kar Wan 2000:107111) also looms large, in the attempt to recover elements from the ancient past ("mummified figments", Fanon) rather than to try and modernise and accommodate to new economical, political and cultural contexts locally and globally (Sugirtharajah 1998:134). Although a literalist "transliteration" hardly contributes to a meaningful translation, especially when foreign terms and expressions dominate, the preference for literal above dynamic or functionalequivalent translations (Aichele 2001:68-74; Van der Merwe 1999:297-299) may eliminate (potential) cultural impositions with the universalist subtext of Western and Christian imperialism from the side of the translators.

One of the most important results of vernacular translations in Africa was the loosening of the controlling grip of the missionaries and their societies (Bediako 1994:246). But such claims are eroded when the close supervisory role of the United Bible Societies (UBS) in the translation projects they are involved in, is considered. ${ }^{35}$ The UBS would insist, for example, on having one of their consultants on the translation team and that their "recommended and supplied" commentaries be consulted (cf Nida and Taber 1974:174-186). Meanwhile, negative perceptions surround some Bible translations in Africa, because local Christians are often not included in the translation activity. ${ }^{36}$ The ideological influence of translation agencies is not lessened when it is claimed that some are representatives of an "extreme right wing Protestant missionary society". ${ }^{37}$ Amidst the difficulty of decisively proving or disproving such allegations, the perception that outside agencies peddle a particular ideology in their involvement with Bible translation in Africa, is often determinative for the evaluation and acceptance of such translations by their intended receptors.

It has to be admitted and accounted for in Bible translation work, that translators - even when denying such intentions - inevitably "operate not only with theological assumptions about their place in God's scheme but also with political assumptions about their place in society and the world" (Lee and Arapović 2001:388, emphasis in original). The minimum requirement for Bible translators, in Africa and elsewhere, would certainly be a critical self-

\footnotetext{
${ }^{35}$ In a recent article which praises the UBS for its effort towards indigenising Bible translation, it is lamented that " $[\mathrm{t}]$ ranslation work is still predominantly in the hands of the West and true communion is an idea which has perhaps not yet fully come true" (Kanyoro 1991:56). This is despite Nida's claim that in $90 \%$ of UBS translation projects, the translators are nationals and the missionaries resource persons (1991:5).

${ }^{36}$ Related concerns emerge e g regularly throughout Kinoti and Waliggo (1997:esp 1-2). Cf Obeng's (1997:21) insistence that meaningful translations for Africa require "African translators who combine a good command of their language and culture with a thorough knowledge of biblical sciences and languages." Schaaf's (1994:142) optimism that in Africa "now almost all translators are Africans" might not be wholly appropriate.

${ }^{37}$ Isichei's (1995:336) reference is to the Wycliffe Bible translators! Schaaf (1994:198, cf :233) questions their translation policy of focusing on the New Testament.
} 
awareness and an ethical approach to the use of their power, in which an alertness to the notion of biblical ownership can greatly assist.

\section{CONCLUSION: A DEBT OWED - THE CHALLENGE OF BIBLE TRANSLATION WORK}

The ambiguous value of Bible translation in Africa cannot be collapsed in the claims, either that translated Bibles became fully-fledged covert agents of the Empire, or that their role was essentially liberatory, fostering a sense of nationalism. Whatever else, Bible translation never was and never will be neutral. The interrelationship between claims to the ownership of the Bible and its translations, redirects the focus of Bible translation work to this relationship and their implications for translation theory and practices in Southern Africa, some of which might also be valuable to consider for Bible translation elsewhere. The appropriation of the Bible in Africa cannot be divorced from a whole range of ideological issues concerning power, which naturally impact on the translation and interpretation of its texts in different ways in different communities. "Controlling, owning, and operating the Bible ... have become strategic appropriations of power to be deployed against a white man's faith that has systematically disempowered blacks in South Africa" (Chidester 1991:25).

It will certainly be interesting to see how, in the future and as the gravity point of Christianity moves further south, the twin but opposite forces of increasing secularization on the one hand, and higher levels of literacy in Africa on the other hand, will affect the development of Christianity and the appropriation of the Bible in Africa. However, the demographic shift of the Church to the South might leave the thought processes and cultural awareness, which are still rooted in the North and which are often sustained by Bible translations and translation practices, untouched. And, if "the Bible in African languages is an indispensable condition of this whole struggle to find an African Christianity" (Schaaf 1994:210), the challenge for translators only grows in importance.

Following the example of countries of the former Soviet Union, Bible translation in Africa will be able to avoid polarisation and conflicting aims to biblical ownership by deliberately eschewing a competitiveness, confessionalism and evangelisation ${ }^{38}$ (cf Lee and Arapović 2001:387). In keeping translated Bibles' close link with claims to ownership of the Bible in mind, other aspects have to receive greater attention in Bible translation work on the African continent. The utilitarian notion that a translated Bible has

\footnotetext{
${ }^{38}$ Pearson (1999:81) argues that the large majority of biblical translators do their work with religious or evangelisation reasons in mind; Walls (1992:24-39) posits an analogy between translation and conversion; and, Carson (1993:57-60) comments that Bible translation's missionary involvement puts the emphasis on simplification and clarity.
} 
become its linguistic community's property, and can therefore be used in ways that a community sees fit, can lead to empowerment as much as to disastrous ethnocentrism. An existential identification with a translated Bible might equally see the Bible inscribing and proscribing identity, stimulating claims to exclusivity.

The ownership of the Bible is underlined by the simple fact that for the majority of people there is only one Bible rather than a plethora of translated Bibles, and that its translated nature is not even considered unless a particular detail of the text is to be contested. The challenge for Bible translation today is to deal with the fact that for the majority of Bible-readers their particular translation simply constitutes the Bible.

\section{Works consulted}

Aichele, G 2001. The control of biblical meaning: Canon as semiotic mechanism. Harrisburg, PA: TPI.

Banana, C S 1993. The case for a new Bible, in Mukonyora, Cox \& Verstraelen 1993:17-32.

Barr, J 1990. The Bible in the modern world. Philadelphia, PA: SCM.

Bauckham, R 1989. The Bible in politics: How to read the Bible politically. London: SPCK. (Third Way Books.)

Bediako, K 1994. Epilogue, in Schaaf 1994:243-54.

Bevans, S B 1992. Models of contextual theology. Maryknoll, NY: Orbis. (Faith and Cultures Series.)

Betz, H D 2000. Review of the concept of biblical theology: An Old Testament perspective (J Barr), in Sweeney, M A (ed), Review of Biblical Literature 2, 513. Atlanta, GA: SBL.

Brenner, A 2000. Foreword, in Aichele, G (ed), Culture, entertainment and the Bible, 7-12. Sheffield: Sheffield Academic Press. (JSTOT 309.)

Carson, D A 1993. New Bible translations: An assessment and prospect, in The Bible in the Twenty First Century, Kee, H C, (ed), 37-67. American Bible Society Symposium Papers. Philadelphia, PA: Trinity.

Camp, C V 1993. Feminist theological hermeneutics: Canon and Christian identity, in Schüssler Fiorenza 1993:154-171.

Chidester, D 1991. Worldview analysis of African indigenous churches. Journal for the Study of Religion 2, 15-29.

Combrink, H J B 1996a. The reception of Matthew in Africa. Scriptura 58, 285-303.

Combrink, H J B 1996b. Translating or transforming: Receiving Matthew in Africa. Scriptura 58, 273-84.

Cormie, L 1991. Revolutions reading the Bible, in Jobeling, D, Day, P L \& Sheppard, G T (eds), The Bible and the politics of exegesis, 173-193. Cleveland, $\mathrm{OH}$ : Pilgrim.

Dahunsi, E A 1972. The problem of translating the Bible into African languages, in Proceedings: The Jerusalem Conference on Black Africa and the Bible, 117120. Mveng, E \& Werblowsky, R J Z (eds). Jerusalem. 
Davies, P 1995. Whose Bible is it anyway? Sheffield: Sheffield Academic Press. (JSOT Sup 204.)

De Villiers, P G R 1993. The Bible and the struggle (for power). Scriptura 45, 1-28.

Dube, M W 2001. "What I have written, I have written" (Jn 19:22)?, in Getui, Maluleke, \& Ukpong 2001:145-163.

Fowl, S E \& Jones, L G 1991. Reading in communion: Scripture and ethics in Christian life. Grand Rapids, MI: Eerdmans.

Frerichs, E S 1988. Introduction, in Frerichs, E S, The Bible and Bibles in America, 18. The Bible in American Culture, vol 6 (SBL). Atlanta, GA: Scholars.

Gallagher, S V 1996. Mapping the hybrid world: Three postcolonial motifs. Semeia 75, 229-240.

Gandhi, L 1998. Postcolonial theory: A critical introduction. New York: Columbia University Press.

Getui, M N, Maluleke, T S \& Ukpong, J S (eds) 2001. Interpreting the New Testament in Africa. Nairobi: Acton.

Gibellini, R 1994. African theologians wonder ... and make some proposals, in Gibellini 1994:1-8.

Gibellini, R (ed) 1994. Paths of African theology. London: SCM.

Griffiths, R 1998. Mrs Thatcher's Bible. Semeia 82, 99-125.

Isichei, E 1995. A history of Christianity in Africa: From antiquity to the present. Grand Rapids, MI: Eerdmans.

Johnston, A 2001. The book eaters: Textuality, modernity, and the London mission society. Semeia $88,13-40$.

Kanyoro, M 1991. Indigenizing translation. Bible Translator 24(2A), 47-56.

Kinoti, H W \& Waliggo, J M (eds) 1997. The Bible in African Christianity: Essays in biblical theology. Nairobi: Acton. (African Christianity Series.)

Lee N C \& Arapović, B 2001. The Bible in political context: New republics from old Yugoslavia and the former Soviet Union. Interpretation 55(4), 378-388.

Maluleke, T S 1996. Black and African theologies in the New World Order: A time to drink from our own wells. JTSA 96, 3-19.

Manus, U C 2001. Paul's speech at the Areopagus: An African reading, in Getui, Maluleke \& Ukpong 2001:213-230.

Martey, E 1993. African theology: Inculturation and liberation. Maryknoll, NY: Orbis.

Mazamisa, W 1995. Re-reading the Bible in the black church: Towards a hermeneutic of orality and literacy. Journal of Black Theology 9(2), 1-26.

Mbiti, J S 1986. Bible and theology in African Christianity. Nairobi: Oxford University Press.

Mbiti, J S 1994. The Bible in African culture, in Gibellini 1994:27-39.

McDonald, J I H 1993. Biblical interpretation and Christian ethics. Cambridge: Cambridge University Press. (New Studies in Christian Ethics.)

Mofokeng, T A 1988. Black Christians, the Bible and liberation. Journal of Black Theology in South Africa 2, 34-42.

Mosala, I J 1989. Biblical hermeneutics and black theology in South Africa. Grand Rapids, MI: Eerdmans.

Mugambi, J N K 1997. The Bible and ecumenism in African Christianity, in Kinoti \& Waliggo 1997:68-85.

Mugambi, J N K 2001. Foundations for an African approach to biblical hermeneutics, in Getui, Maluleke \& Ukpong 2001:9-29. 
Mukonyora, I, Cox, J L \& Verstraelen, FJ (eds) 1993. "Rewriting" the Bible: The real issues: Perspectives from with Biblical and religious studies in Zimbabwe.

Gweru: Mambo. (Religious and Theological Series 1.)

Müller, M 1996. The first Bible of the church: A plea for the Septuagint. Copenhagen International Seminar 1. Sheffield: Sheffield Academic Press. (JSNT Suppl Series 206.)

Ndungu, N 1997. The Bible in an African independent church, in Kinoti, \& Waliggo 1997:58-67.

Nida, E A 1991. Trends in Bible translating within the United Bible Societies: A historical perspective. Bible Translator 42(2A), 2-4.

Nthamburi, Z \& Waruta, D 1997. Biblical hermeneutics in African instituted churches, in Kinoti \& Waliggo 1997:40-57.

Obeng, E A 1997. The use of biblical critical methods in rooting the Scriptures in Africa, in Kinoti, \& Waliggo 1997:8-24.

Oduyoye, M A 1995. Daughters of Anowa: African women and patriarchy. Maryknoll, NY: Orbis.

Parratt, J 1995. Reinventing Christianity: African theology today. Grand Rapids, MI: Eerdmans.

Pearson, B W R 1999. Remainderless translations: Implications of the tradition concerning the translation of the LXX for modern translation theory, in Porter \& Hess 1999:63-84.

Pollard, A B, III. 1995. An Afrocentric gospel for South Africa. Journal of Black Theology in South Africa 9(1), 38-51.

Porter, S E \& Hess, R S (eds) 1999. Translating the Bible: Problems and prospects. Sheffield: Sheffield Academic Press. (JSNT Suppl Series 173.)

Punt, J 1998. The Bible, its status and African Christian theologies: Foundational document or stumbling block? Religion \& Theology 5(3), 265-310.

Saayman, W 1991. "Who owns the schools will own Africa": Christian mission, education and culture in Africa. Journal for the Study of Religion 4(2), 29-44.

Sanneh, L 1989. Translating the Message: The missionary impact on culture. Maryknoll, NY: Orbis. (American Society of Missiology Series 13.)

Schaaf, Y 1994. On their way rejoicing: The history and the role of the Bible in Africa, tr by $P$ Ellingworth. Carlisle: Paternoster. (African Challenge Series.)

Schreiter, R J 1985. Constructing local theologies. Maryknoll, NY: Orbis.

Schüssler Fiorenza E 1993. Introduction: Transforming the legacy of The Women's Bible, in Schüssler Fiorenza 1993:1-24.

Schüssler Fiorenza E (ed) 1993. Searching the Scriptures, vol 1: A feminist introduction. London: SCM.

Scroggs, R 1995. The Bible as foundational document. Interpretation 49(1), 17-30.

Segovia, F F 1995. The text as other: Towards a Hispanic American hermeneutic, in Smith-Christopher 1995:276-298.

Segovia, F F 2000. Reading-across: Intercultural criticism and textual posture, in Segovia 2000:59-83.

Segovia, F F (ed) 2000. Interpreting beyond borders: The Bible and postcolonialism, vol 3. Sheffield: Sheffield Academic Press.

Smit, D J 1991. The Bible and ethos in a new South Africa. Scriptura 37, 51-67.

Smit, D J 1994. A story of contextual hermeneutics and the integrity of New Testament interpretation in South Africa. Neotestamentica 28(2), 265-289. 
Smith, W C 1993. What is Scripture? A comparative approach. London: SCM.

Smith-Christopher, D (ed) 1995. Text \& experience: Towards a cultural exegesis of the Bible. Sheffield: Sheffield Academic Press. (Biblical Seminar 35.)

Stine, P C (ed) 1992. Bible translation and the spread of the church: The last 200 years. Leiden: Brill. (Studies in Christian Mission 2.)

Sugirtharajah, R S 1998. Asian biblical hermeneutics and postcolonialism: Contesting the interpretations. Maryknoll, NY: Orbis. (The Bible and Liberation Series.)

Sze-Kar Wan 2000. Does diaspora identity imply some sort of universality? An AsianAmerican reading of Galatians, in Segovia 2000:107-131.

Trebolle Barrera, J C 1998. The Jewish Bible and the Christian Bible. An introduction to the history of the Bible, tr by W G E Watson. Leiden: Brill.

Van Aarde, A G 1994. The epistemic status of the New Testament and the emancipatory living of the historical Jesus in engaged hermeneutics. Neotestamentica 28(2), 575-596.

Van der Merwe, C H J 1999. 'n Konkordante vertaling van die Bybel in Afrikaans: Is dit hoegenaamd verantwoordbaar, en hoe sal dit lyk? NGTT 40 (3\&4), 293303.

Van Toorn, P 2001. Before the second reformation: Nineteenth-century aboriginal mediations of the Bible in Van Diemen's land. Semeia 88, 41-69.

Waliggo, J M 1997. Bible and catechism in Uganda, in Kinoti \& Waliggo 1997:179195.

Walls, A F 1992. The translation principle in Christian history, in Stine 1992:24-39.

Wambudta, D N 1980. Hermeneutics and the search for theologia Africana. Africa Theological Journal 9(2), 29-39.

West, G O 1994. The challenge of Ideologiekritik: The Biblical text as site of struggle, in Mouton, J \& Lategan, B C (eds), The relevance of theology for the 1990's, 273289. Pretoria: HSRC.

West, G O 1999. Local is lekker, but ubuntu is best: Indigenous reading resources from a South African perspective, in Sugirtharajah, R S, Vernacular hermeneutics, 37-51. Sheffield: Sheffield Academic Press. (The Bible and Postcolonialism, 2.)

West, G O 2001. A real presence, subsumed by others: The Bible in colonial and postcolonial contexts. Semeia 88, 199-214.

West, G O 2002. The Bible as bola: Among the foundations of African biblical apprehensions. JTSA 112, 23-37.

Westphal, M 1997. Post-Kantian reflections on the importance of hermeneutics, in Lundin, R (ed), Disciplining Hermeneutics: Interpretation in Christian Perspective, 57-66. Grand Rapids, MI: Eerdmans.

Whiteman, D L. 1992. Bible translation and social and cultural development, in Stine 1992:120-44. 